\title{
Aterosklerozun Patofizyolojisi ve Risk Faktörleri
}

\author{
Başak TANRIVERDİ, Şermin SAVAŞ TETIKK
}

ÖZ

Dünyada ve ülkemizde ateroskleroz ve komplikasyonları en önde gelen ölüm nedenidir. Ateroskleroz, tipik lezyonu ateroma plakları olan orta ve büyük çaplı arterlerin intima tabakalarını etkileyen bir hastalıktır. Endotel disfonksiyonu aterosklerotik süreçteki temel mekanizmalardan biridir. Klasik ve yeni belirlenen risk faktörleri endotelde vazodilatatör cevabın azalmasına yol açan kronik hasarlanma oluştururlar. Böylece endotelde oluşan vazokonstriksiyon, inflamatuvar hücrelerin birikimi, düz kas hücrelerinin migrasyonu, sitokin üretiminin artışı gibi olaylar aterosklerotik plak oluşumuna neden olurlar. Endotel disfonksiyonu yalnız plak oluşumuna neden olan aterosklerotik sürecin ilk basamağı olmakla kalmaz, ayrıca oluşan plağın büyümesine, çatlamasına ve trombojenik olayların tetiklenmesine de neden olur. Hiperkolesterolemi; ateroskleroz patogenezinde rol oynayan en önemli faktördür. Epidemiyoloji çalışmaları, pek çok genetik ve çevresel faktör arasında artmış serum kolesterol düzeylerinin, diğer bilinen risk faktörlerinin yokluğunda bile ateroskleroz gelişimine tek başına yeterli olduğunu göstermektedir. Bu çalışmada köpük hücrelerin oluşumunu sağlayarak ateroskleroz patogenezine katkısı bulunduğu düşünülen lipoproteinler incelenirken, bu fenomene katıldığı düşünülen pek çok parametrenin de ele alınarak değerlendirilmesi amaçlanmıştır.

Anahtar kelimeler: Ateroskleroz, risk faktörleri, aterosklerozun patofizyolojisi
Başak TANRIVERDİ, Şermin SAVAŞ TETIKK

Marmara Üniversitesi, Eczacilı Fakültesi, Biyokimya Anabilim Dall, Haydarpaşa, 34668/İstanbul,Türkiye

Corresponding author:

Şermin SAVAŞ TETIK

e-posta:stetik@marmara.edu.tr

Submitted / Gönderilme: 04.06 .2016

Accepted / Kabul: 14.08.2016
Revised / Düzeltme: 11.08 .2016

\section{GİRiş}

Kardiyovasküler hastalıklar ve inme gibi ateroskleroz kaynaklı hastalıklar, tüm dünyada, özellikle endüstrileşmiş toplumlarda en önemli morbidite ve mortalite nedenidir. Ateroskleroz, atar damar duvarlarının kalınlaşması ve sertleşmesi ile karakterize, kalp krizleri ve inmelerin en önemli sebebidir. Aterosklerotik lezyon kronik inflamatuvar bir süreçtir. Bu sürece damar endoteli, monositler/makrofajlar, düz kas hücreleri, bazı büyüme faktörleri ve sitokinler katılır. Epidemiyoloji çalışmaları, pek çok genetik ve çevresel faktör arasında artmış serum kolesterol düzeylerinin, diğer bilinen risk faktörlerinin yokluğunda bile ateroskleroz gelişimine tek başına yeterli olduğunu göstermektedir.

\section{Normal Arter Duvarı}

Normal arter duvarı intima, medya ve adventisya tabakalarından oluşur. İntima tabakası, lümene bakan yüzde tek sıra dizilmiş endotel hücreleri, bunları destekleyen subendotelyal matriks ve bazal membran intimasindan oluşur. İntima tabakası elastik lif̧̧iklerin membranda yoğunlaşması ile meydana gelen elastika interna ile medya tabakasından ayrilır. Medya tabakası, arter duvarının 
orta ve en kalın tabakasıdır. Kollajen elastik lifler ve glikozaminoglikanlardan oluşan matriks içinde yoğun olarak dizilmiş düz kas hücrelerinden oluşur. Damar duvarında bulunan düz kas hücrelerinin tamamına yakını bu tabakada yer almaktadır. Damar düz kas hücreleri fibroblast benzeri hücrelere dönüşebilme yeteneğine sahiptir. Damar tonusunu salgılanan bir kısım mediatörlerle medya tabakası sağlar (1). Adventisya tabakası ${ }_{2}$ en dış tabakadır. Gevşek bağ dokusu yapısındaki bu tabaka kollajen liflerden vasovazorumlardan ve sinir uçlarından oluşur). İntima ve medya tabakasına göre seyrek hücre dağılımına sahiptir (2).

\section{Endotel Yapisi}

Endotel damar sistemi içinde yer alan ve birçok fizyolojik ve patolojik olaylarda çok önemli düzenleyici rolü olan, kan ve damar duvarı (düz kaslar) arasına sınırlandırılmış, mezoderm kaynaklı tek katlı yassı epitelyum doku olup vücudumuzun en büyük organıdır (3). Yüzeyindeki glikoproteinler ile glikozaminoglikanların negatif yük kazandırdığı endotel hücreler, hücresel ve hormonal moleküllerle etkileşim içinde olduklarından çok sayıda reseptör taşımaktadırlar. Trombosit agregasyon inhibisyonu, koagülasyon aktivasyonunun inhibisyonu, fibrinolizis fonksiyonları ile pıhtılaşmayı önleyici bir yüzey oluşturmak, ayrıca doku ve dolaşım arasında madde alışverişi, vasküler tonusun düzenlenmesi, lökosit ve trombosit adhezyonunun regülasyonu gibi görevleri vardır (4).

\subsection{Endotel Disfonksiyonu}

Endotel disfonksiyonu, nitrik oksit üretiminde bozulma ve/veya endotel-kaynakll, endotelin-1 (ET-1), angiotensin ve oksidanlar gibi gevşeme ve kasılma faktörlerindeki dengesizliği ifade eder. NO amino asit argininin NO sentetaz enzimi ile NO ve L-sitruline dönüştürülmesi ile elde edilir. Endotel-kaynaklı gevşetici faktörler arasında ve vasküler tonusun ve vazodilatasyonun ayarlanmasında önemli rol oynar. NO vazodilatör etkinin yanı sıra, vasküler hasar, inflamasyon ve trombozise karşı koruyucudur. NO lökositlerin endotele adezyonunu inhibe eder, vasküler düz kas hücrelerinin nonproliferatif konumda kalmasını sağlar ve trombosit agregasyonunu sinırlar (5).

Hipertansiyon, diyabet ve hiperkolesterolemi gibi geleneksel kardiyovasküler risk faktörleri endotelin koruyucu fonksiyonunun bozulmasına neden olur (Şekil 1). Hiperkolesterolemi normal koşullarda lökositlerin sıkı adezyonuna dirençli olan endotel tabakasına kandaki lökositlerin bağlamasına neden olur (6). Okside düşük dansiteli lipoprotein (oxLDL) endotel aktivasyonuna ve NO’nun hücre içi konsantrasyonunu azaltarak biyolojik karakterinin değişmesine neden olur. Bu endotelyal değişiklikler damar duvarında inflamasyona yol açarak aterosklerotik lezyonların bağlama ve ilerlemesinde bir ilk basmak oluşturur (7).

\section{Aterosklerozun Histopatolojisi}

Uzun yillar boyunca patologlar tarafindan yapılmış olan morfolojik incelemeler ışığında üç tip aterosklerotik plak tarif edilmiştir. Bunlar yağlı çizgilenmeler, fibröz plaklar ve komplike plaklardır (8). Yağlı çizgilenmeler çok sayıda lipid damlacıkları ile dolu makrofajların intimada birikmesiyle oluşurlar (köpük hücreleri). Lipid damlacıkları spesifik bir temizleyici reseptör ailesi tarafından alınan okside olmuş veya toplanmış LDL'den kaynaklanan kolesterol esterlerinden oluşur. Yağlı çizgilenmeler kan akımını etkilemezler (9). Fibröz plaklarda lipidler hem makrofaj köpük hücrelerinde hem de ekstraselüler matriks içerisinde bulunurlar. İntima düz kas hücreleri ve ekstraselüler matriks proteinlerinin birikmesine bağlı olarak kalınlaşmıştır. Lipidler ve makrofajlar $\mathrm{T}$ lenfosit, bazen $\mathrm{B}$ lenfosit ve mast hücreleriyle beraber çekirdek kısmında bulunurken düz kas hücreleri ve matriks subendotelyal bölgede bulunarak diğer hücreleri saran fibröz bir şapka oluştururlar. İnce fibröz şapkası, lipid ve enflamatuar hücrelerden zengin çekirdeği olan plakların yırtılma riski yüksektir. Komplike lezyonlar lipid, enflamatuar hücreler ve fibröz dokuya ek olarak hematom, kanama veya trombotik depozitler de içeren plaklardır. Koroner ateroskleroza bağlı morbidite ve mortalite esas olarak bu lezyonlara bağlıdır (10).

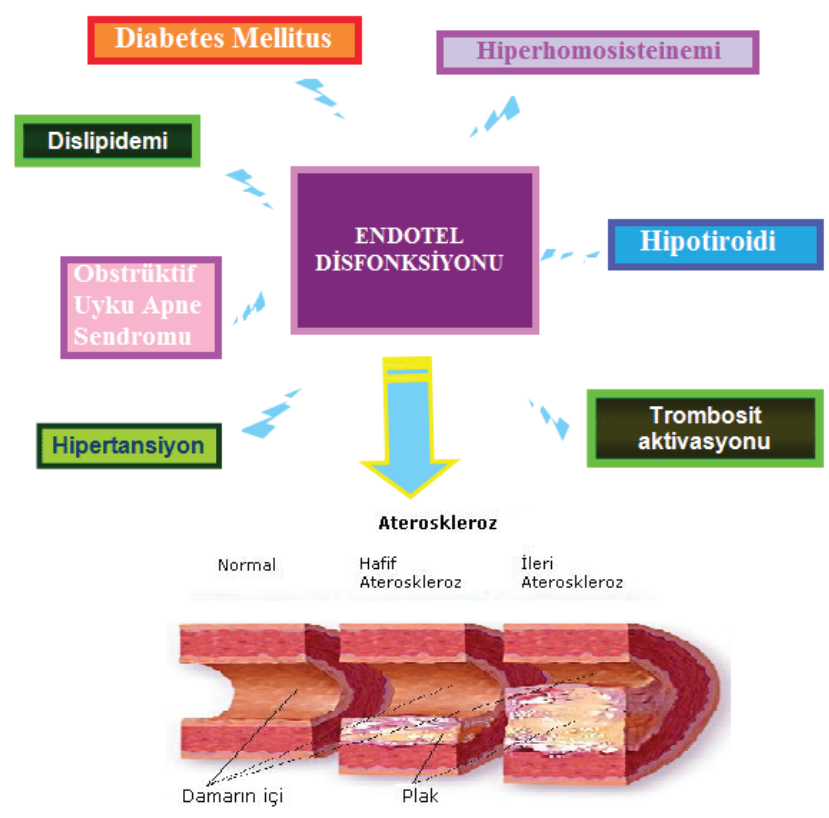

Şekil 1. Endotel Disfonksiyonu ve Ateroskleroz 
Amerikan Kalp Birliği Damar Lezyonları Komitesi lezyonun ilerleme sürecini 8 değişik safhaya ayıran yeni bir sınıflandırma ortaya koymuştur (11):

- Tip 1 lezyon en erken lezyondur ve minör lipid birikimleri ve seyrek makrofaj köpük hücreleri ile karakterizedir. Doğumdan hemen sonra bebeklerin \%45'inde Tip 1 lezyon vardır. Bu lezyon çocukluğun ilk yıllarında azalır ama 10 yaş civarında tekrar artmaya başlar.

- Tip 2 lezyonlarda makrofaj köpük hücreleri daha fazla sayıdadır ve klasik olarak yağlı çizgilenmeler şeklinde organize olmuştur. Tip 2 lezyonlarda az miktarda T-lenfosit hücreleri, mast hücreleri ve lipitle dolu düz kas hücreleri de vardır.

- Tip 3 lezyon klasik patoloji tarafından aterosklerotik plak veya aterom olarak tanımlayan ilk safhayı yansitır. Tip 2 lezyona göre en önemli ayırt edici özelliği küçük ekstraselüler lipid depozitlerinin varlığıdır. Tip 3 lezyonun varlığının gelecekteki klinik hastalığın göstergesi olduğuna inanilmaktadir.

- Tip 4 lezyonlar ekstraselüler lipid miktarı artmış ve hücreden yoksun bir kolesterol havuzu oluşmuştur. Lezyon genellikle yarım ay şeklindedir ve damar duvarının kalınlığını arttırır. Bu safhada orijinal lümen hacmini korumak için arterde yeniden yapılanma oluşur. Damarın dış kontürü oval şeklini alır ve bu nedenle anjiografik görüntülenmeleri çok zordur. Yeni yapılmış anjiogramda normal görünen bir koroner arterin bir bölümünde tıkanıklık veya önemli derecede stenoz geliştiği zaman yırtılmış Tip 4 lezyonlarda trombus oluşumu en muhtemel açıklamadır.

- Tip 5 lezyonlar lipid çekirdeği kaplayan fibröz dokuda artış ile karakterizedir. Kollajen çoğu zaman bu lezyonun önde gelen özelliği olup plak hacminin çoğundan sorumludur. Kapillerin plak içerisine ilerlemesi de Tip 5 lezyonda görülen bir özelliktir. Tip 5 lezyonlar çoğunlukla büyüktür ve bu nedenle arterde remodeling ile yeni bir oluşum gerçekleşmez. Sonuçta lümen daralır. Düz kontürlü olan bu daralma genellikle anjiografi ile saptanabilir. Tip 5 lezyonlar Tip 4 lezyonlara göre daha fazla fibröz doku içermelerine rağmen yırtılmaların çoğu bu lezyonda görülür. Bunun nedeni olarak tipik olarak plakla normal intima arasındaki sinır bölgesinde ince bir fibröz doku tabakasının bulunması ve lezyonun lümeni daraltıp laminar kan akımlarına daha fazla maruz kalması düşünülmektedir.

- Tip 6 lezyonlar trombotik depozitler ve kanama içeren plaklardır. Bu lezyonun gelişmesinin temel nedeni plak yırtılmasıdır. Ayrıca subendotelyal dokuda fissürler, erozyonlar ve ülserasyonlar da sık olarak gözlenir. Akut miyokardial enfarktüs ve kararsız anjina pektoris gibi klinik olaylar çoğunlukla Tip 6 lezyona bağlıdır. Yırtılmış bir plağın üzerinde oluşan trombusün çoğu fibrinolitik sistem tarafından elimine edilir. Ancak materyalin bir kısmı plağın içine girebilir. Bu süreç anjiografi ile birlikte görülebilen hızlı plak ilerleyişi vakalarının çoğundan sorumludur. Trombotik materyal yavaş yavaş düz kas hücreleri tarafından kolonize olur ve bu hücreler trombotik materyali fibröz doku haline dönüştürürler. Bu iyileşme sürecinin sonucu olarak lezyon Tip 5 morfolojisine geri döner.

- Tip 7 ve Tip 8 lezyonlar lipid içermeyen veya az miktarda lipid içeren, ön planda kalsiyum depositleri (Tip 7 lezyon) ve kollejenden (Tip 8 lezyon) oluşan ilerlemiş lezyonlardır. Plak kalsifikasyonunun kinlik önemi belirgin değildir fakat lezyonları daha az elastik ve gerilim kuvvetlerine daha duyarlı hale getirdikleri düşünülmektedir. Tip 8 lezyonlar Tip 5 ve Tip 6 lezyonlara göre daha stabildir. Tip 5 ve 6 lezyonlar Tip 8 lezyona dönüştürülebilirse klinik açıdan fayda sağlanabilir.

\section{Aterosklerotik Risk Faktörleri}

Aterosklerotik kalp ve damar hastalıkları dünyada tüm ölüm nedenleri arasında en başta gelen sebeptir. Yapılan çalışmalar bazı etkenlerin ateroskleroz ile ilişkili olduğunu ortaya çıkarmıştır (Tablo1). İnsanlarda yapılan çeşitli çalışmalarla total kolesterol, HDL kolesterol, vücut kitle indeksi gibi değişik faktörlerin kardiyovasküler riskle ilişkisi ortaya koyulmuştur. Hipertansiyon, diyabet gibi kronik hastalıklar da ateroskleroz risk faktörleri arasında yer almaktadır. Bu hastalıklara eşlik eden bir dislipidemi durumu olduğunda, ateroskleroz riski daha da artmaktadir (12).

Tablo 1. Aterosklerotik Risk Faktörleri (13).

\begin{tabular}{|c|c|}
\hline $\begin{array}{l}\text { MAJÖR RİSK } \\
\text { FAKTÖRLERI }\end{array}$ & $\begin{array}{l}\text { I.Değisstirilebilir Risk Faktörleri } \\
\text { 1. Dislipidemi } \\
\bullet \quad \text { Hiperkolesterolemi } \\
\text { 2. Hipertansiyon kolesterol düşüklüğü } \\
\text { 3. Sigara } \\
\text { 4. Diabetes Mellitus } \\
\text { II.Değiştirilemeyen Risk Faktörleri } \\
\text { 1. Yaş } \\
\text { 2. Cinsiyet } \\
\text { 3. Kalıtım }\end{array}$ \\
\hline $\begin{array}{l}\text { MİNÖR RİSK } \\
\text { FAKTÖRLERİ }\end{array}$ & $\begin{array}{l}\text { 1. Hipertrigliseridemi } \\
\text { 2. Fiziksel aktivite azlığ } 1 \\
\text { 3. Obezite } \\
\text { 4. Stresli kişilik yapısı }\end{array}$ \\
\hline $\begin{array}{l}\text { YENİ RISSK } \\
\text { FAKTÖRLERİ }\end{array}$ & $\begin{array}{l}\text { 1. Koagulasyon eğilimini arttıran faktörler } \\
\text { : Pibrinojen } \\
\text { Plazminojen aktivatör inhibitör-1 (PAI-1) } \\
\text { Hiperhomosisteinemi } \\
\text { Lipoprotein (a) yüksekliği } \\
\text { 2. Enflamasyon göstergeleri } \\
\text { (fibrinojen, CRP, Cu, Fe, IL-6, TNF- } \alpha \text { gibi) }\end{array}$ \\
\hline
\end{tabular}




\subsection{Dislipidemi}

Lipoprotein metabolizmasındaki herhangi bir bozukluk hastanın plazma lipid ve kolesterol düzeylerinin ölçülmesiyle saptanır. Plazma lipoproteinlerinin primer bozuklukları kalıtsaldır ve primer hiperlipoproteinemi teşhisi konulabilmesi için öncelikle sekonder nedenlerin varlı̆̆ araştırılmalıdır. Lipoprotein metabolizma bozuklukları, major plazma lipoproteinleri esas alınarak aşağıdaki şekilde sinıflandırılabilir (14):

Tip I: LPL eksikliği veya LPL' nin inaktive olmasına neden olan apoC-II eksikliğine bağlı hipertrigliserideminin görüldügü tablodur. Şilomikronlar ve VLDL klirensinin yavaş, HDL ve LDL kolesterol düzeyinin düşük olduğu, koroner hastalık riskinde artışın olmadığı hiperlipoproteinemi tipidir. Yağ miktarı düşük, karbonhidrat düzeyi yüksek diyetle tedavi edilebilir.

Tip II: LDL klirens hızında azalma nedeniyle serum LDL kolesterol düzeylerinde artışa ve hiperkolesterolemiye yol açar. Ateroskleroz ve koroner hastalık riskinin bulunduğu tip II nin iki şekli bulunur. Tip IIa, kusurlu LDL reseptörleri veya apoB-100 ligand bölgesinde mutasyon sonucu görülür. Tip IIb de ek olarak VLDL düzeyinde artma görülür.

Tip III: ApoE’ nin üç izoformundan (E2, E3, E4) apoE2' nin reseptöre bağlanma kusuruyla ortaya çıkan nadir görülen ( 1/10000 kişi) bir hastalıktır.

Tip IV: Otozomal dominant geçişli olduğu düşünülmektedir. Hem VLDL' nin aşırı üretimi ve hem de katabolizmasının azalması söz konusudur. Kolesterol düzeyi VLDL miktarına paralel olarak artar. Genellikle HDL ve LDL düzeyi normalden azdır. Ailesel hipertrigliseridemiye KKH, tip II diyabet, şişmanlık, alkolizm eşlik edebilir.

Tip V: Şilomikronlar ve VLDL düzeyi artmış, HDL ve LDL kolesterolü ise azalmıştır. LPL veya apoC-II' nin eksikliğinden kaynaklandığı düşünülmekte ancak nedeni tam olarak bilinmemektedir.

Hiperkolesterolemi ateroskleroz patogenezinde rol oynayan en önemli faktördür. Hiperkolesterolemide ilk aşamada gerçekleşen olay, endotel hücrelerinde intersellüler adezyon molekül-1 (ICAM-1), vasküler hücre adezyon molekül-1 (VCAM-1) gibi adezyon molekülleri ile monosit kemotaksisinde önemli rolü olan monosit kemoatraktan protein-1 (MCP-1)'in üretimidir. Bunun sonucu, monositler endoteli geçip subendoteliyal alana yerleşirler.
Aterosklerozun gelişiminde önemi olan diğer bir etken ise enflamasyondur. Son yirmi yılda yapılan çalışmalar monosit/ makrofaj ve T-lenfositlerinin endotel ve düz kas hücreleri ile etkileşiminin aterosklerotik lezyonların gelişimindeki rolünü göstermiştir. Arter duvarındaki enflamatuvar süreci başlatan faktörlerin; oxLDL, mekanik hasar, immunolojik, toksik veya infeksiyöz etkenler (Chlamydia enfeksiyonu, herpes virüsler) veya bunların bileşimi olduğu sanılmaktadır. Bu etkenler endotel hücrelerinin yüzey yapısını değiştirir ve endotel hücrelerinin LDL alımı artar (15).

LDL'nin endotelde oksidasyona uğraması aterosklerozun gelişiminde başlatıcı etkendir. LDL, lipooksijenaz, myeloperoksidaz, reaktif nitrojen türleri veya metal iyonlarıyla okside olabilir. LDL' nin metal iyonlarıyla oksidasyonu üç basamaktan oluşur (16):

- 1. Başlangıç basamağı: Endojen antioksidanların tüketimi

- 2. İlerleme basamağı: Doymamış yağ asitlerinin lipid hidroperoksitlerine oksidasyonu

- 3. Sonlanma basamağı: Hidroperoksitlerin reaktif aldehitlere dönüşümü

oxLDL, LDL' nin bağlanamadığı çöpçü reseptörleri (Scavenger reseptör A) ve $\mathrm{CD} 36$ reseptörlerine bağlanır. Bu reseptörler hücre içindeki kolesterol düzeyi tarafından kontrol edilemez ve subendotel yerleşimli makrofajlar oxLDL' yi kontrolsüz bir biçimde hücre içine alarak köpük hücrelerini meydana getirirler (17). oxLDL, MCP-1 sekresyonunu arttırarak daha fazla monositin endotel yüzeyine infiltrasyonuna, makrofaj koloni uyarıcı faktör (M-CSF) salınımı ile de daha fazla makrofaj üretilmesine böylece köpük hücre oluşumunun artmasına neden olur (18). oxLDL'nin düz kas hücrelerine göçü, endotel hücreleri, makrofaj ve düz kas hücrelerinin PDGF salgılanmasını uyarmaları sonucu artar (19).

Köpük hücrelerinin toplanması ve düz kas hücrelerinde göç ve proliferasyonun artması intimanın kalınlaşmasına neden olur. Arteriyal lümenin daralması, vazodilatör kapasitenin daha fazla bozulmasına yol açar. oxLDL vazokonstriktör endotelin-1 (ET-1) üretimini arttırırken (20), vazodilatör NO üretimini azaltır (21).

oxLDL nin, LDL den daha fazla aterojenik olmasının dört önemli nedeni vardır (22):

- oxLDL, arter duvarındaki hücreler için sitotoksiktir. Hücresel hasar, öncelikle endotel hasarı oluşturabilir. 
Böylece aterosklerotik olaylar zinciri başlatılır.

- oxLDL, arter intimasinda kolesterol birikmesi sonucu sentezlenmeleri önlenemeyen çöpçü reseptörler aracılığıyla makrofaj içine alınır, böylece köpük hücre ve lezyon oluşumuna katılır.

- oxLDL, monosit kemotaksisi için düz kas hücre ve endotelden salınan faktörler gibi kimyasal çekici (kemoattraktan) maddedir. Onların damar intimasına göçünü hızlandırır.

- oxLDL, makrofajların intimadan plazmaya kaçışını önleyerek arter intimasındaki kalış sürelerini uzatır.

Lektin benzeri okside LDL reseptörü-1 (LOX-1) ilk olarak 1997 yılında sığır aortik endotel hücrelerinden köken alan komplementer DNA ekspresyonu kütüphanesi kullanılarak keşfedilmiştir (23). LOX-1, insan koroner arterlerinde okside LDL reseptörü için tek sınıftır ve E sınıfı süpürücü reseptörlerden olup diğer sınıflardan farklı yapıdadır (24).

LOX-1 ateroskleroz gelişiminde en önemli üç hücre olan makrofajlarda, vasküler düz kas hücreleri (VDKH) ve damar endotel hücrelerinde eksprese edilmektedir. Ateroskleroz gelişmemiş aortada LOX-1 ekspresyonu saptanamazken, erken aterosklerotik lezyonlar bulunan karotis arterlerinin endotel hücrelerindeki LOX-1 ekspresyonu ileri aterosklerotik lezyonların bulunduğu hücrelerden daha sıklıkla pozitiftir. LOX -1 trombosit endotelyum etkileşimine aracılık eden bir hücre-adezyon molekülü gibi fonksiyon görmektedir ve LOX-1'in aterosklerozu başlangıcında inflamasyonu indükleyen endotoksin ile ilişkisi bulunmaktadır (25).

Ig-OxLDL Beaumont tarafından 1965'te multiple miyelomlu ve hiperlipidemili bir hastada tesadüfen keşfedilmiştir (26). Riesen ve Noseda ise 1975 'te primer kronik poliartritli ve meme kanserli hastalarda Ig-OxLDL'nin varlığını göstermişlerdir (27). Salonen'e göre Ig-OxLDL titresi ve ateroskleroz gelişimi arasında pozitif bir korelasyon vardır (28).

Aşağıda anlatılan üç değişiklik Ig-OxLDL'nin modifiye LDL'ye bağlanması sonucu oluşur (29):

- Ig-OxLDL'nin LDLye bağlanmasından sonra, LDL metabolizmasinda gecikme ve hiperlipidemide artma görülür.. Ox-LDL'nin makrofajlar ve diğer apopitotik hücreler tarafindan alınması ve fagositozunun bu antikorlar tarafından inhibe edildiği ileri sürülmektedir..

- Antikorlar, LDL’nin lipaz reseptörlerine bağlanabilirler.
Bu yüzden lipaz bu partikülleri parçalayamaz.

- Ig-OxLDL direkt lipaza bağlanır ve lipolizi engeller. $\mathrm{Bu}$ mekanizma, eklampsi veya koroner arter hastalığ1 (KAH) gibi hiperlipidemiden etkilenmiş bazı olguları açıllayabilir.

\subsection{Diabetes Mellitus}

Diabetes Mellitus kardiyovasküler hastalıkların gelişiminde en önemli risk faktörleri arasındadır. Yapılan çalışmalarda, 20 yıllık takipler sonrasında aterosklerotik kardiyovasküler hastalık gelişme oranının diyabetik hastalarda, diyabetik olmayanlara göre 2-3 kat arttı̆̆ı gösterilmiştir (30).

Diyabetik hastalarda oluşan endotel disfonksiyonu ve hızlanmış aterosklerozun kardiyovasküler komplikasyonlar gibi makrovasküler komplikasyonların oluşumunda önemli rol oynadığ 1 düşünülmektedir.. Karakteristik olarak diyabetik hastalarda trigliserit değerleri yükselmekte, HDL düşmekte ve aterojenik küçük ve yoğun LDL kolesterol partikülleri artmaktadır (31). Diabetes Mellitusta aterosklerozun sık görülme sebepleri aşağıdaki şekilde sıralanabilir (32):

- Diyabet ve dislipidemiler

- Diyabet ve hipertansiyon - Diyabet ve endotel

- Diyabet ve koagülasyon

- Diyabet ve fibrinoliz

- Diyabet ve oksidatif stress

- Diyabet ve hemoreoloji

İnsülin çok düşük yoğunluklu lipoproteinlerin çevresel kana verilmesi olayına dolaylı ve doğrudan etkiler yapar; Öncelikle İnsülin apo-B fosforilasyonunu arttırır. Fosforilasyon, apoB’nin trigliseridlerle bir araya gelerek çok düşük yoğunluklu lipoprotein (VLDL) oluşturmasını güçleştirir. Ayrıca mitokondride yer alan "mitokondrial transfer protein" adı verilen bir proteini inhibe eden insülin, VLDL sentezini azaltmış olur. İkinci etki olarak İnsülin, kanda dolaşan serbest yağ asitlerini azaltır. Serbest yağ asitlerinin, VLDL sentezi üzerine uyarıcı etkisi vardır. Dislipidemi, özellikle kan şekerinin düzensiz olduğu devrelerde daha sıktır. Tip 2 Diabet vakalarında ise hipertrigliseridemi hem sıklıkla hem de daha kalıcı şekilde ortaya çıkar. LDL glikozillenirse, trombositleri aktive ederek, daha çok tromboksan salınımı yapmalarına yol açar. Glikozillenmiş LDL yalnız tromboksan salınımını arttırmakla değil, prostasiklin (PGI2) salınımını azaltmakla da etki gösterir (32). 


\subsection{Hipertansiyon}

Yüksek kan basıncını diagnoz, prognoz, ve önleme komisyonu $\geq 140 \mathrm{mmHg}$ sistolik veya $\geq 90 \mathrm{mmHg}$ diyastolik kan basınçlarını veya bir anti-hipertansif ilaç kullanıyor olmayı hipertansiyon olarak tanımlamıştır (33). Birçok çalışmada, yüksek kan basıncının kardiyovasküler kalp hastalıkları için risk faktörü olduğu belirtilmiştir. Bu ilişki yaşlı veya genç, erkek veya kadın olmakla değişmemektedir. (34).

Aterosklerozun patojenezi ile ilgili olarak üç ana değişik görüş ileri sürülmektedir (35):

1. Lipid infiltrasyon teorisi,

2. Trombojenik teori,

3. Vasküler dinamik teori.

- Yüksek kan basıncının lipid infiltrasyonunu artırması veya intima yüzeyinde değişikliklere yol açarak trombosit fibrin mikrotrombüslerini oluşturması suretiyle aterojenezi hızlandırdığı düşünülmektedir (35). Sistemik hipertansiyonla birlikte koroner arter kalp hastalığ 1 (KAKH) olan olgularda lipoprotein fenotiplerinin çoğunluğunun (\% 89.66) aterojenik fenotip örneği (Tip Ha) göstermesi, aterojenezisde önemli bir rolünün olduğunu göstermektedir. Sadece sistemik hipertansiyonu olan olgularda ise buna benzer bir şekilde lipoprotein fenotipi dağılımının görülmesi (\% 76.58) sistemik hipertansiyonun KAKH gelişmesinde mekanik etkisinin yanı sıra, aterojenik hiperlipoproteinemiye sebep olmasının da katkısının olabileceği bildirilmiştir (36).

\subsection{Trombositler}

Kanamayı durdurma, trombositlerin primer fonksiyonu olarak tanımlanmıştır. Endotel bütünlüğü bozulduğunda ya da hasara uğradığında trombositler damar duvarına yapışır. Trombosit yüzeyinde bulunan integrin reseptör ailesine ait gliko protein (GP) reseptörlerinden biri olan GPIIb-IIIa reseptörleri en çok bulunan GP'lerden biridir (her trombositte 80.000 kadar). İstirahat durumunda GPIIb-IIIa reseptörlerinin fibrinojene afinitesi düşük düzeydedir. Agonist uyarılması ile bu reseptörde konformasyonel değişiklikler olarak fibrinojene afinite belirgin şekilde artar. Trombosit agregasyonu temel olarak GPIIb-IIIảya bağlı fibrinojen ile olur (37).

Damar duvarına trombositlerin yapışması, $\mathrm{PGI}_{2}$ gibi endotelyal vazodilatör faktörleri ve $\mathrm{NO}$ gibi trombosit adezyonunu önleyen faktörleri uyarır. Adezyon gerçekleştiğinde trombositler şişmeye başlar ve yüzeyi düzensiz bir hal alır. Yüzeyinde birçok radyal oluşum ortaya çıkar. Kontraktil proteinlerinin güçlü bir şekilde kasılması sonucu granüllerden proagregatuar faktörlerin (TXA2, ADP, serotonin, kalsiyum ve trombosit aktive edici faktör) sentez ve salınımlarının uyarılışı, trombosit aktivasyonu ve agregasyonunu artırır (38).

Trombositlerin anormal bir şekilde çoğalmasının, ateroskleroz gelişimindeki en erken basamaklardan biri olduğuna inanılmaktadır. Arterlerin dallanma noktaları çevresindeki hemodinamik stresler vasküler endotelin hasarlaşmasına ve plak oluşumuna neden olur. Trombüs oluşumu sırasında en erken değişiklik plak rüptürünün ardından gelişen trombositlerin subendotelyal kollajene adezyonu ve aktivasyonudur. Oluşan aterosklerotik plaklarda endotel hücrelerindeki hasarlaşma trombositlerin agregasyonuna neden olur. Biriken trombositlerden açı̆̆a çıkan maddeler endoteli, intimayı, makrofajları ve düz kas hücrelerini etkiler (39).

Trombosit hacmi trombosit fonksiyonunu belirleyen bir parametredir. Daha büyük hacimli trombositler hemostatik olarak daha aktiftir. Trombosit çapı ve aktivitesindeki değişiklikler intrakoroner trombüs oluşumunda ve akut miyokard infarktüsü gelişiminde etkili olmaktadır (39).

\subsection{Hipotiroidi}

Tiroid hormonu hemen hemen tüm dokularda ve metabolik süreçlerde etkin olmasına rağmen etkileri en belirgin olarak kardiyovasküler sistemde karşımıza çıkmaktadır. Tiroid hormonu kardiyovasküler etkilerini doğrudan ve dolaylı olarak göstermektedir. Doğrudan etkilerini miyositleri reseptör ve nükleer düzeyde etkileyerek, dolaylı etkilerini ise hemodinamiyi ve otonomik sinir sisteminde sempatik tonusu degiştirerek gösterir. Kalp hızında, atım hacminde ve kardiyak atım hacminde azalma, sistemik vasküler rezistansta artma görülür (40).

Kolesterol ve trigliserid düzeylerindeki artış, aterosklerozu artırmaktadır. Ayrıca serum kreatin fosfokinaz iskelet kası formu kreatin kinaz-MM (CK-MM) yüksek olarak saptanmaktadır. Perikardiyal efüzyon ve kalp yetersizliği görülebilmektedir. $\mathrm{T}_{4}^{\prime}$ ün yaklaşık \%3'ü başlıca yüksek dansiteli lipoprotein-kolesterol (HDL-K) (\%92) ve daha az olarak da düşük dansiteli lipoprotein-kolesterol (LDL-K) (\%6.7) olmak üzere lipoproteinlere bağlanır. $\mathrm{T}_{4}$-LDL kompleksi LDL reseptörü tarafindan farkedilir ve bu olay, hücre içine $\mathrm{T}_{4}$ girişinin bir mekanizmasını oluşturur. Ayrıca 
tiroid hormonunun LDL reseptörünü aktive etme yeteneği de vardır. Hipotiroidizmde periferal dokudaki lipoprotein lipaz enziminin aktivitesiazalır. İnsan yağ dokusundaki lipolizin adrenerjik regülasyonu da azalır. Bu durumda lipoprotein lipazın etki ettiği prekürsör olan çok düşük dansiteli lipoprotein-kolesterol (VLDL-K) kanda birikir. Hepatik trigliserid lipaz aktivitesinin azalmış olması da olaya katkıda bulunur (41).

\subsection{Hiperhomosisteinemi}

Homosistein, metiyoninden üretilen ve tiyol içeren esansiyel bir aminoasiddir. Homosistein, kofaktör olarak vitamin B-12 kullanırsa remetilasyonla tekrar metiyonine; vitamin B-6 kullanılırsa transsülfürasyonla sisteine metabolize olabilir. İnsan plazmasinda, homosistein birkaç formda bulunur. Yaklaşık \%70-80'i temel olarak albumine olmak üzere proteinlere disülfid bağları ile bağlıdır. Geri kalan homosistein oksidlenerek dimerler (homosistin) veya sisteinle birleşerek miks disülfidler oluşturur. Homosistein, çok küçük bir oranda $(<\% 1)$ dolaşımda serbest olarak bulunur. (42).

Hiperhomosisteineminin etkilediği birçok aterojenik mekanizma vardır. Homosistein plazmada metabolize olduğunda reaktif oksijen ürünleri oluşturarak endotel hasarını artırır. Ayrıca damar duvarının intima tabakasının kalınlaşması, damar intima tabakasındaki düz kas hücre proliferasyonunun uyarılması, damar duvarındaki lipid birikiminin artması, trombosit ve lökositlerin aktivasyonu, LDL oksidasyonunun artışı, platelet trombaksan sentezinin aktivasyonuna da yol açmaktadır. Ayrıca homosistein, koagülasyon sisteminin birçok faktörlerini etkileyerek trombin oluşumunu hızlandırır (42). Yapılmış metaanalizler incelendiğinde hiperhomosisteineminin artmış vasküler hastalık riski ile ilişkili olduğu rapor edilmiştir. Homosistein

\section{$\operatorname{XXXXX}$}

\section{ABSTRACT}

Atherosclerosis and its complications is the leading cause of death both in our country and in the world. Atherosclerosis is a disease that affects the intima layers of medium and large arteries with its typical lesions "atherosclerotic plaques". Endothelial dysfunction is one of the basic mechanisms in the atherosclerotic process. Classic and newly identified risk factors leading to a decrease in the vasodilator response creates chronic injury. Thus, vasoconstriction composed in endothelium, accumulation of inflammatory cells, smooth muscle cell migration, cytokine production cause the increase of events such as the formation of atherosclerotic plaques. Endothelial dysfunction is not only yüksekliğinin bağımsız bir risk faktörü olduğu ama diğer klasik risk faktörleri ile birlikteliğinin hastalık oluşumunu belirginleştirdiği saptanmıştır (43).

Aterosklerozda, endotel hasarı kritik öneme sahip olup hastalık belirtilerinin ortaya çıkmasına neden olur. $\mathrm{Bu}$ nedenle, homosisteinin bazı etkileri endotelyal disfonksiyon ve daha spesifik olarak nitrik oksidin salınımı ve/veya etkilerinin azalması sonucu ortaya çıkmaktadır (43).

\subsection{Obstrüktif Uyku Apne Sendromu (OUAS)}

OUAS'da, ateroskleroz gelişiminde rol oynayan çok çeşitli proinflamatuvar ve protrombotik faktörlerin salınımında artış vardır. Hem aterosklerotik vasküler olaylarda hem de OUAS'da önemli ölçüde endotel disfonksiyonu bulunmaktadır. Sağlıklı kişilerle karşılaştırıldığında, OUAS'lı hastalarda ön kol damarlarında endotel fonksiyonunun bozulduğu (asetil kolin uyarısına vazodilatör yanıtın azalmış olduğu) gösterilmiştir (44). Ayrıca OUAS’ın şiddeti ile de endotel disfonksiyonu arasında anlamlı bir ilişki olduğu da saptanmıştır. Apne ve hipoksi, endotel hasarı ile sonuçlanabilir. Hipoksi direkt olarak dokularda NO sentezini etkilemektedir.

Endotel hücresinin hipoksik strese vereceği yanıt bu stresin süresine göre iki şekilde olmaktadır (45):

1. Kısa süreli hipoksi, damar duvarı tonusu ve kan akımında fizyolojik ve geri dönüşümlü bir yapılanmaya sebep olacaktır.

2. Kronik hipoksik stres, damarlarda ve çevre dokularda, düz kas proliferasyonu ve fibrozisle sonuçlanan geri dönüşsüz bir yapılanmaya yol açacaktır.

the first step of the atherosclerotic plaque formation process, but also cause triggering of atherogenic events cracking and the growth of plaque. The most important factor that plays a role in the pathogenesis of atherosclerosis is hypercholesterolemia. Epidemiological studies indicate that along many genetic and environmental factors, increased serum cholesterol levels is enough alone for development of atherosclerosis in the absence of other known risk factors. In this study, lipoproteins that are considered to contribute formation of the pathogenesis of atherosclerosis by creating foam cells were examined and it is aimed to evaluate this phenomenon considering the many parameters joining it.

Keywords: Atherosclerosis, risk factors, pathophysiology of atherosclerosis 


\section{KAYNAKLAR}

1. Halit Z. Ateroskleroz patogenezi. Deneysel ve Klinik Tip Derg 2012; 29: 101-6.

2. Vallance PJT, Webb DJ. Vascular endothelium, its physiology and pathophysiology. CRC Press, 2003.

3. Akçakoyun M. Koroner arter hastalığı olgularında koroner risk faktörleri ile endotel fonksiyonları arasındaki ilişki (Uzmanlık Tezi). Koşuyolu Kalp Eğitim ve Araştırma Hastanesi, İstanbul. 2004.

4. Yalın TY, Mete K. Endotel Disfonksiyonu. Pamukkale Tip Derg 2011; 4:152-7.

5. Gauthier TW, Scalia R, Murohara T, Guo JP, Lefer AM. Nitric oxide protects against leukocyte-endothelium interactions in the early stages of hypercholesterolemia. Arterioscler Thromb Vasc Biol 1995;15:1652-9.

6. Libby P, Ridker PM, Maseri A. Inflammation and atherosclerosis. Circulation. 2002;105:1135-43.

7. Cominacini L, Rigoni A, Pasini AF, Garbin U, Davoli A, Campagnola M, Pastorino AM, Lo Cascio V, Sawamura T. The binding of oxidized low-density lipoprotein (ox-LDL) to oxLDL receptor-1 in endothelial cells reduces the intracellular concentration of nitric oxide through an increased production of superoxide. J Biol Chem 2001;276:13750-5.

8. Harrison DG. Endothelial function and oxidant stress. Clin Cardiol. 1997;20:11-17.

9. Özdoğu H. İnflamasyonda baş aktör endotel. Türkiye Hematoloji Derneği (6. ilk basamak kursu), Ankara. 2007.

10. Stary HC, Chandler AB, Dinsmore RE, Fuster V, Glagov S, Insull W Jr, Rosenfeld ME, Schwartz CJ, Wagner WD, Wissler RW. A definition of advanced types of atherosclerotic lesions and histological classification of atherosclerosis. A report from the Committee on Vascular Lesions of the Council on Arteriosclerosis ,American Heart Association. Circulation 1995 ;92:1355-13.

11. Kardiyoloji Miniatlas, 1. Baskı. AND danışmanlık, eğitim, yayıncılık ve organizasyon Ltd. Şti. 2003, pp 155-162.

12. Seyfettin Ü. Hiperkolesterolemi İle Oluşabilecek Oksidatif Stresin ve Monosit CD36 Reseptör Ekspresyonunun Ateroskleroz Riski Açısından Değerlendirilmesi (Uzmanlık Tezi). MÜ Tip Fakültesi Biyokimya Anabillim Dalı, İstanbul. 2012.

13. Yilmaz G. Atorvastatin kullanan dislipidemi hastalarında tedavi öncesi ve 3 ay sonrası serum Paraoksonaz-1 ve okside LDL düzeyleri (Uzmanlık Tezi). Taksim Eğitim ve Araştırma Hastanesi, İstanbul. 2008.

14. Binder CJ, Chang MK, Shaw PX, Miller YI, Hartvigsen K, Dewan A, Witztum JL. Innate and acquired immunity in atherogenesis. Nat Med 2002;8:1218-26.

15. Steinberg D. Atherogenesis in perspective: Hypercholesterolemia and inflammation as partners in crime. Nat Med 2002;8:1211-7.

16. Carr AC, McCall MR, Frei B. Oxidation of LDL by myeloperoxidase and reactive nitrogen species: reaction pathways and antioxidant protection. Arterioscler Thromb Vasc Biol 2000 Jul;20:1716-23.

17. Doi H, Kugiyama K, Oka H, Sugiyama S, Ogata N, Koide SI, Nakamura SI, Yasue H. Remnant lipoproteins induce proatherothrombogenic molecules in endothelial cells through a redox-sensitive mechanism. Circulation 2000;102:670-6.

18. Stiko-Rahm A, Hultgardh-Nilsson A, Regnstrom J, Hamsten A, Nilsson J. Native and oxidized LDL enhances production of PDGF AA and the surface expression of PDGF receptors in cultured human smooth muscle cells. Arterioscler Thromb 1992;12:1099-1109.

19. Boulanger CM, Tanner FC, Bea ML, Hahn AW, Werner A, Luscher TF. Oxidized low density lipoproteins induce mRNA expression and release of endothelin from human and porcine endothelium. Circ Res 1992;70:1191-7.

20. Liao JK, Shin WS, Lee WY, Clark SL. Oxidized low-density lipoprotein decreases the expression of endothelial nitric oxide synthase. J Biol Chem 1995;270:319-24.

21. Kockx MM. Apoptosis in the atherosclerotic plaque: quantitative and qualitative aspects. Arterioscler. Thromb Vasc Biol 1998;18:1519-22.

22. Kugiyama K, Sakamoto T, Misumi I, Sugiyama S, Ohgushi M, Ogawa H, Horiguchi M, Yasue H. Transferable lipids in oxidized low-density lipoprotein stimulate plasminogen activator inhibitor-1 and inhibit tissue-type plasminogen activator release from endothelial cells. Circ Res 1993;73:33543.

23. Chen XP, DU GH. Lectin-like oxidized lowdensity lipoprotein receptor-1: protein, ligands, expression and pathophysiological significance. Chin Med J 2007;120:421-6.

24. Özlem K, Hülya YA. Okside LDL Reseptörü-1 (LOX-1) ve Kardiyovasküler Hastalıklarla İlişkisi. Tıp Araştırmaları Derg 2014;12:145-52.

25. Sakurai K, Sawamura T. Stress and Vascular Responses: Endothelial Dysfunction via Lectin- Like Oxidized LowDensity Lipoprotein Receptor-1: Close Relationships with Oxidative Stress. J Pharmacol Sci 2003; 91:182-6.

26. Beaumont JL. Hyperlipidemia caused by anti-beta-lipoprotein autoantibodies. A new pathological entity. CR Acad Sci Hebd Seances Acad Sci D 1965;261:4563-6.

27. Riesen W, Noseda G. Antibodies against lipoproteins in man. Occurence and significance. Klin Wschr 1975;53:353-61.

28. Salonen JT, Ylä-Herttuala S, Yamamoto R, Butler S, Korpela H, Salonen R, Nyyssönen K, Palinski W, Witztum JL. Autoantibody against oxidized LDL and progression of carotid atherosclerosis. Lancet 1992; 339: 883-7.

29. Shaw PX, Hörkkö S, Tsimikas S, Chang MK, Palinski W, Silverman GJ, Chen PP, Witztum JL. Human-derived antioxidized LDL autoantibody blocks uptake of oxidized LDL by macrophages and localizes to atherosclerotic lesions in vivo. Arterioscler Thromb Vase Biol 2001; 21:1333-9.

30. Bernstein RK. 2008 American Diabetes Association Clinical Guidelines Comments. Avaible from: http://www. diabetesbook.com/cms/articles/9-diabetes-in-control/5576richardk-bernstein-md-face-facn-fccws- Last access: 16th May 2011.

31. Summary of Revisions for the 2009 Clinical Practice Recommendations. Diabetes Care 2009; 32 Suppl 1: S3-5. Erratum in: Diabetes Care 2009; 32:754.

32. Assmann, G. Dabetic Dyslipidaemia Results From the Prospective Cardiovascular Münster Procam Study. Clinician 1990; 8 (1): 3-11.

33. Roger VL, Go AS, Lloyd-Jones DM, Benjamin EJ, Berry JD, 
Borden WB, Bravata DM, Dai S, Ford ES, Fox CS, Fullerton HJ, Gillespie C, Hailpern SM, Heit JA, Howard VJ, Kissela BM, Kittner SJ, Lackland DT, Lichtman JH, Lisabeth LD, Makuc DM, Marcus GM, Marelli A, Matchar DB, Moy CS, Mozaffarian D, Mussolino ME, Nichol G, Paynter NP, Soliman EZ, Sorlie PD, Sotoodehnia N, Turan TN, Virani SS, Wong ND, Woo D, Turner MB; American Heart Association Statistics Committee and Stroke Statistics Subcommittee. Heart disease and stroke statistics--2012 update: a report from the American Heart Association. Circulation 2012;125:188-97. Erratum in Circulation 2012;125:e1001.

34. Third Report of the National Cholesterol Education Program (NCEP) Expert Panel on Detection, Evaluation, and Treatment of High Blood Cholesterol in Adults (Adult Treatment Panel III) final report. Circulation 2002;106:3143-421.

35. Helgeland A, Hjermann I, Leren P, Enger S, Holme I. HDL cholesterol and antihypertensive drugs: the Oslo Study. $\mathrm{Br}$ Med J 1978;2:403.

36. Sokolow M, Mcilory ME. Clinical cardiology, second edition. WB Saunders Com., New York. 1979, pp 124.

37. Tetik Ş, Ak K, Yardımcı KT. Trombosit fonksiyon testlerini etkileyen faktörler. Cumhuriyet Med J 2012; 34:123-7.

38. Wallentin L, Lindahl B, Siegbahn A. Unstable angina and non-
ST-elevation MI. In: Cardiology, 1st ed. Editors: Crawford MH, DiMarco JP, Paulus WJUSA. Elsevier Science Limited. 2001.

39. Yuvanç U, Çiçek D, Yeşilbursa D, Karaağaç K, Şentürk T, Siğirli D, Jordan J. Akut miyokard infarktüsünde ortalama trombosit hacminin bir yıllık mortalite ve revaskülarizasyon ihtiyacı üzerine etkisi. MN-Kardiyoloji Derg 2004;11:416-20.

40. Toft AD, Boon NA. Thyroid disease and the heart. Heart 2000;84:455-60.

41. Klein I, Ojamaa K. Thyroid hormone and the cardiovascular system. N Engl J Med 2001;344:501-9.

42. Chen C, Halkos ME, Surowiec SM, Conklin BS, Lin PH, Lumsden AB. Effects of homocysteine on smooth muscle cell proliferation in both cell culture and artery perfusion culture models. J Surg Res 2000;88:26-33.

43. Tetik Ş, Ak K. Kardiyovasküler hastalıklarda trombosit fonksiyon testleri: patofizyolojiden klinik yaklaşıma. Cumhuriyet Med J 2010; 32: 264-74.

44. Carlson JT, Rangemark C, Hedner JA. Attenuated endothelium dependent vascular relaxation in patients with sleep apnea. J Hypertens 1996; 14: 577-84.

45. Faller DV. Endothelial cell responses to hypoxic stress. Clin Exp Pharmacol Physiol 1999; 26: 74-84. 